\title{
Potential Anti-diabetic Effects and Safety of Aqueous Extracts of Urtica dioica Collected from Narok County, Kenya
}

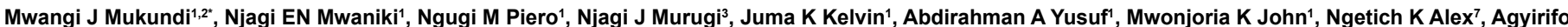
S Daniel ${ }^{1,4}$, Gathumbi K Peter ${ }^{5}$ and Muchugi N Alice ${ }^{6}$

${ }^{1}$ Department of Biochemistry and Biotechnology, School of Pure and Applied Sciences, Kenyatta University, Nairobi, Kenya

${ }^{2}$ Department of Science, Narok Teachers Training College, Narok, Kenya

${ }^{3}$ Department of Environmental and Population Health, School of Public Health, Kenyatta University, Nairobi, Kenya

${ }^{4}$ Department of Molecular Biology and Biotechnology, University of Cape Coast, Ghana

${ }^{5}$ Department of Veterinary Pathology, Microbiology and Parasitology, College of Agriculture and Veterinary Sciences, University of Nairobi, Nairobi, Kenya

${ }^{6}$ Genetic Resources Unit, World Agroforestry Centre, Nairobi

${ }^{7}$ Department of Biochemistry, Technical University of Kenya, Kenya

\begin{abstract}
Drug bio screening for potential anti-diabetics is scientifically motivated by the desire to discover newer, safer and affordable drugs that complement conventional strategies for management of diabetes. Urtica dioica grows naturally in many parts of Africa with a wide variety use in traditional medicine and diet. However, scientific validation for use of $U$. dioica has not been done for anti-diabetic activity. The aim of the study was to determine the antidiabetic effects of aqueous extracts of $U$. dioica in alloxan induced mice and the safety of $U$. dioica on mice models. The plant extracts were administered orally at doses of $25 \mathrm{mg} / \mathrm{kg}, 100 \mathrm{mg} / \mathrm{kg}, 200 \mathrm{mg} / \mathrm{kg}$ and $300 \mathrm{mg} / \mathrm{kg}$ which is the common route used in traditional herbal medicine administration. Evaluation for toxicity was determined at a dose of $1000 \mathrm{mg} / \mathrm{kg}$ body weight aqueous extracts of $U$. dioica. The results from the study indicated that the plant extracts exhibited insulin mimetic anti-diabetic activity. Evaluation for toxicity also indicated that a dose of $1000 \mathrm{mg} / \mathrm{kg} \mathrm{bw}$ preserved the integrity of liver, kidney and lipid profiles for biochemical markers. Moreover, there was no significant change in the hematological and leucocyte counts. There was no significant change in gross body weight, organ body weight and histopathological changes on tissues of the body organs in this study. Furthermore, qualitative and quantitative phytochemical screening of aqueous leaf extracts of $U$. dioica indicated the presence of phenols, alkaloids, flavonoids, tannins and saponins. Various levels of different mineral elements were also recorded. In conclusion, this study confirmed that $U$. dioica at a dose of $50 \mathrm{mg} / \mathrm{kg}, 100 \mathrm{mg} / \mathrm{kg}, 200 \mathrm{mg} / \mathrm{kg}$ and $300 \mathrm{mg} / \mathrm{kg}$ body weights possessed anti-diabetic activity. It is also safe for use at a dose of $1000 \mathrm{mg} / \mathrm{kg}$ body weight. More studies should be explored on the potential anti-diabetic effects using other routes of administration.
\end{abstract}

Keywords: Urtica dioica; Diabetes mellitus; Aqueous extracts; Antidiabetic activity; Phytochemicals

\section{Introduction}

Diabetes is a group of metabolic diseases characterized by hyperglycemia resulting from defects in insulin secretion, insulin action, or both [1]. Hyperglycemia which is the main symptom of diabetes mellitus generates Reactive Oxygen Species (ROS) which cause lipid peroxidation and membrane damage [2]. The word diabetes was coined by the Greek physician Aretaeus in the first century A.D. In the $17^{\text {th }}$ century, Willis observed that the urine of diabetics was wonderfully sweet as if imbued with honey or sugar. The presence of sugar in the urine of diabetics was demonstrated [3]

Diabetes mellitus is considered as one of the five causes of death in the world [4]. In 1995, the World Health Organization reported that approximately 150 million persons worldwide had diabetes mellitus, and this number may double by 2025 [5]. Alternative strategies to the current modern pharmacotherapy of diabetes mellitus are urgently needed because of the inability of existing modern therapies to control all the pathological aspects of the disorder, as well as the enormous cost and poor availability of the modern therapies for many rural populations in developing countries [6].

Because of these limitations, there is continued need for new and more effective therapies which would improve diabetic control and also reduce associated risk factors like hyperlipidemia, hypertension and so on. A lot of alternative therapies have emerged with herbal medicine being inclusive. Though numerous traditional medicinal plants are reported to have hypoglycemic properties, many of them have not been proven to be effective in lowering blood glucose levels in severe diabetes [7]. There is need to explore herbal medicines in the context of modern science and validate them accordingly. In recent years, investigation on herbal medicines has become progressively important in the search for a new, effective and safe therapeutic agent for the treatment of diabetes. More than 200 pure bioactive principles isolated from plants have been demonstrated to have blood glucose-lowering effect [8].

Urtica dioica L. (common as stinging nettle) belongs to family Urticaceae and is a dioecious herbaceous annual or perennial plant. In this family, more than 600 species in 45 genera are reported. Urtica is one of the most important genera and contains 30 species. Laxative, diuretic and menorrhagic effects have been reported for decoction prepared from the leaves of the nettle. In folk medicine, nettle has been used to treat iron deficiency anemia due to its high content of iron and also used to stop excessive menstrual bleeding, hematuria and nosebleeds. The root of nettle has been employed for treating asthma [9].

*Corresponding author: Mwangi J Mukundi, Department of Science, Narok Teachers, Training College, P.O. Box 709, Narok, Kenya, Tel: +254721279669; Email: johnmukundi1973@gmail.com

Received April 28, 2016; Accepted May 25, 2017; Published May 30, 2017

Citation: Mukundi MJ, Mwaniki NEN, Piero NM, Murugi NJ, Kelvin JK, et al. (2017) Potential Anti-diabetic Effects and Safety of Aqueous Extracts of Urtica dioica Collected from Narok County, Kenya. Pharm Anal Acta 7: 548. doi: 10.4172/21532435.1000548

Copyright: (c) 2017 Mukundi MJ, et al. This is an open-access article distributed under the terms of the Creative Commons Attribution License, which permits unrestricted use, distribution, and reproduction in any medium, provided the original author and source are credited. 
Most animal studies have shown the beneficial effects of $U$. dioica in diabetes management. Human studies have demonstrated effectiveness of $U$. dioica in decreasing blood glucose in both pancreatic and extra pancreatic pathways. Regarding pancreatic effects, it has been suggested that it is a potent stimulator of insulin release from $\beta$-cells and has shown protective effect on $\beta$-cells in diabetic rats. Inhibited intestinal absorption of glucose and inhibitory effects on the $\alpha$-amylase activity are extra pancreatic mechanisms [10].

\section{Material and Methods}

\section{Collection of plant material}

Leaves of Urtica dioica were collected from Loita division, Narok County, Kenya. Coordinates for the collection point as at E $36 \mathrm{M}, \mathrm{N}$ 0797065, UTM 9822965 and ALT 2109. This was determined using a hand held GPS machine model type garmin extrex. Cross identification with vernacular name of the plant was done before validation by a qualified taxonomist at the East Africa herbarium, National Museums of Kenya (NMK). A voucher specimen was deposited at the NMK and assigned a voucher specimen number (JM06).

\section{Preparation of aqueous extracts}

The collected plant materials were dried under a shade for four weeks, chopped into small pieces and then ground into fine powder using a mechanical grinder. It was filtered through a $40 \mathrm{~mm}$ mesh sieve for collection of fine powder. Water extracts was prepared using $100 \mathrm{~g}$ of the fine powder in $1 \mathrm{~L}$ of distilled water, at $60^{\circ} \mathrm{C}$ in a metallic shaker for duration of $6 \mathrm{~h}$. The extract was first decanted and then filtered using a Whatman filter paper number 1 using buchner funnel. It was then stored at $4^{\circ} \mathrm{C}$ in refrigerator. Freeze drying was done using a Modulyo freeze dryer (Edward, England) for $48 \mathrm{~h}$. The yield was stored in a freezer at $-20^{\circ} \mathrm{C}$

\section{Experimental animals}

Male Swiss albino mice of about 20-30 g in weight were used in the study after they were left for some time to acclimatize in the animals at the department of Biochemistry and Biotechnology, Kenyatta University. Polypropylene cages were used in the maintenance of the mice. Equal $12 \mathrm{~h}$ day light and $12 \mathrm{~h}$ night sequence was maintained throughout the study. The room temperatures were regulated at $25 \pm$ $2^{\circ} \mathrm{C}$. The animals were all fed on standard mice pellets sourced from Unga Feeds Limited, Kenya. Moreover, water SAS supplied to the animals ad libitum. The Principles of care and handling of Laboratory Animal was followed [11].

\section{Experimental design}

This study was divided into seven groups (Table 1). Different treatment groups were administered with $0.1 \mathrm{ml}$ of the physiological saline and extracts except for group III, which was administered with $0.06 \mathrm{mg}$ of glibenclamide as a reference drug.

\section{Induction of hyperglycemia}

Diabetes was induced using $186.9 \mathrm{mg} / \mathrm{kg}$ body weight of alloxanmonohydrate (Sigma Chemicals, St. Louis, $\mathrm{OH}$ ) administered by intraperitoneal injection [12]. First, the animals were fasted, but allowed free access to water. The animals were fasted for 8-12 h, but allowed free access to water. Blood glucose levels was then measured 48 $\mathrm{h}$ later using an automatic glucose analyzer (On call plus-ACON LAB Inc.-USA), using glucometer strips, lot number 2014-09 following the manufacturer instructions.

\begin{tabular}{|c|c|c|c|}
\hline Animal group & Status & Treatment & Number of mice \\
\hline I & Normal (untreated) & Normal saline & 5 \\
\hline II & Diabetic & Normal saline & 5 \\
\hline III & Diabetic & Reference drug & 5 \\
\hline IV & Diabetic & $50 \mathrm{mg} / \mathrm{kg} \mathrm{bw}$ extract & 5 \\
\hline V & Diabetic & $100 \mathrm{mg} / \mathrm{kg} \mathrm{bw}$ extract & 5 \\
\hline VI & Diabetic & $200 \mathrm{mg} / \mathrm{kg}$ bw extract & 5 \\
\hline VII & Diabetic & $300 \mathrm{mg} / \mathrm{kg}$ bw extract & 5 \\
\hline & \multicolumn{2}{|c|}{ Table 1: Experimental study design. } \\
\hline
\end{tabular}

\section{In vivo blood sampling and glucose determination}

Mice tails were first sterilized with $10 \%$ alcohol before nipping at the tip. Blood samples were then collected at durations of 1-4, 12 and 24 h. The blood glucose levels were determined immediately by following the procedure described above. Blood glucose levels above $2000 \mathrm{mg} / \mathrm{L}$ $(>11.1 \mathrm{mmol} / \mathrm{L})$, was considered diabetic and suitable for use in the study.

\section{In vivo evaluation of toxicity}

Toxicity was evaluated at a dose of $1000 \mathrm{mg} / \mathrm{kg}$ body weight administered orally. This was compared to untreated control group of animals. Each of the groups had five mice. Treatment was administered on a daily basis for 28 days. Morphological, behavioral and mortality characteristics of the animals was observed. On the $29^{\text {th }}$ day, mice tail was nipped for collection of peripheral blood for determination of hematological markers in EDTA coated vial. All groups of mice were euthanized using chloroform, blood was collected by cardiac puncture for determination of biochemical markers, and body organs collected for histological assessment.

\section{Determination of body and organ weight of animals}

An electronic beam balance, model type: BL-220H, (Shimadzu Corporation Japan) was used in the determination of body weight for each mouse at the start of the experiment and thereafter, at the end of every 7 days starting the first day to the $28^{\text {th }}$ day before the animals was euthanized [13]. After the animals were dissected, and blood drawn for biochemical analysis, the body organs were carefully extracted, weighed before they could be preserved in $10 \%$ formalin awaiting histological analysis.

\section{Determination of hematological parameters}

Hematological parameters and indices such as Red Blood Cells (RBC), White Blood Cells (WBC), haemoglobin concentration, Mean Corpuscular Hemoglobin ( $\mathrm{MCH})$, Mean Corpuscular Hemoglobin Concentration (MCHC), Mean Corpuscular Volume (MCV), Red Cell Distribution Width (RDW) and Platelet Distribution Width (PDW), were determined using the Coulter Counter System (Beckman Coulter, ThermoFisher, UK) following manufacturer's instructions [14]. In addition, air-dried thin blood films was prepared and stained with Giemsa stain. They were examined microscopically for determination of the differential counts using magnification X200 and X400 for differential WBC counts.

\section{Determination of biochemical parameters}

Blood collected via cardiac puncture for biochemical parameters was collected into vials without anticoagulant and allowed to stand for 3 $\mathrm{h}$ to ensure complete clotting for preparation of serum. The clotted blood was first broken, centrifuged and clear serum aspirated and stored at $-20^{\circ} \mathrm{C}$. This was used for determination of Aspartate Aminotransferase (AST), Alanine Aminotransferase (ALT), Alkaline Phosphatase 
(ALP), $\gamma$-glutamyltransferase (GGT), Lactate Dehydrogenase (LDH), $a$-amylase and Creatinine Kinase (CK) using the Olympus 640 Chemistry Autoanalyser. All biochemical tests were performed using standard operating procedures described by the manufacturer as used previously by Abdirahman et al. [15].

\section{Histopathology}

All formalin fixed tissues were processed using standard procedures for histopathology [16]. Haematoxylin and eosin stain was used and tissues were assessed microscopically for pathological changes. Comparison was made between the different treatment groups against the control for any variation in the tissue characteristics and reported.

\section{Qualitative and quantitative phytochemical screening}

Standard procedures for qualitative determination of phytochemicals were used in determining the availability of various phytochemicals: Tannins, Alkaloids, saponins, flavonoids, phenolics, phlobatannin [17-19].

\section{Determination of the mineral content of the plant extracts}

Mineral content was determined using the TXRF method and Atomic Absorption Spectrophotometry (AAS). In using the TXRF method: One gram of each sample was prepared in triplicates and added to $10 \mathrm{ml}$ of double distilled water. Gallium was used as a standard and was added into each of the sample at $20 \mu \mathrm{L}$ of $1000 \mathrm{ppm}$. Every sample was mixed using a vortex mixer for $1 \mathrm{~min}$. Aliquotes of $10 \mu \mathrm{L}$ of each of the sample were prepared triplicates and pipetted into clean quartz carriers using a micro-pipette. The carriers were then dried in an oven to evaporate the liquid. Every carrier was irradiated at 1000 seconds in S2 Picofox TXRF spectrometer machine. The measured spectrum was analysed using S2 picofox software for determination of the concentrations of identified elements based on intensities and analyte peak elements compared to the internal standard [20]. Moreover, Atomic Absorption Spectrophotometry (AAS); Model: 210VGP (Scientific equipment), was used for the quantification of magnesium, chromium and vanadium in the plant extracts. Wet samples for use in AAS were prepared using standard procedures. Concentrations were recorded and reported in $\mu \mathrm{g} / \mathrm{g}$ dry matter [21].

\section{Data analysis}

The data collected was organized and prepared using Microsoft Excel sheets. It was cleaned and exported into SPSS software for statistical analysis version 20. Data was reported as mean \pm Standard Deviation (SD). Differences between the means of different treatment groups of animals in the efficacy study was done using ANOVA and followed by a Post ANOVA statistical test (Tukey's post hoc analysis). Comparison of differences in the means between two groups was done using unpaired student $t$ - test. Level of significance difference was reported at $\mathrm{p}<0.05$ for all the comparisons.

\section{Results}

\section{In vivo hypoglycemic activity of Urtica dioica}

Leaf extracts yielded a 5\% light brown powder after freeze drying. Orally administered extracts of Urtica dioica lowered blood glucose levels at all the four doses (Table 2), from the first hour to the sixth hour in a dose dependent manner. By the second hour the extract had lowered the blood glucose levels by $51 \%, 54 \%, 57 \%$, and $60 \%$, respectively for the four doses, compared to $36 \%$ for the conventional oral drug, glibenclamide (Figure 1). The reduction in blood glucose levels when compared to the negative control was statistically significant $(\mathrm{p} \leq 0.05)$

\section{Effect of oral administration of Urtica dioica plant extract on body and organ weights of mice.}

Oral administration of $U$. dioica at a dose of $1000 \mathrm{mg} / \mathrm{kg}$ body weight caused a significant lower rate of weekly weight gain to the mice when compared to the control (Table 3). Similarly, there was a significant decrease in the weight of testes $(\mathrm{p}<0.05)$. All the other organs were not adversely affected $(\mathrm{p}>0.05)$ (Table 4$)$.

\section{Determination of hematological parameters}

Aqueous extracts of $U$. dioica at a dose of $1000 \mathrm{mg} / \mathrm{kg}$ bw administered orally did cause a significant change in the hematological parameters as compared to control mice (Table 5). Similarly, the differential counts for leucocytes and related parameters were similar to that of control $(\mathrm{p}>0.05)$ (Table 6).

\section{Determination of biochemical parameters}

The integrity of the liver for elevation of most of the liver enzymes was preserved except for the significant decrease in $a$-amylase $(\alpha-A M Y L)(p<0.05)$ compared to the control mice (Table 7$)$ after oral administration of $U$. dioica. Similarly, there was a significant increase in creatinine $(\mathrm{p}<0.05)$ compared to the control mice in the kidney (Table 8). Moreover, Total Cholesterol (TC) and LDL-C as markers for the lipid profiles were significantly lowered compared to the control mice (Table 9).

\section{Histopathology}

There were no major histopathological changes in the organs examined for the liver, heart, kidney, lungs, brain, testis, intestines and spleen when compared with controls. Focal mononuclear cell infiltration was observed in most organs including the kidney, heart and liver occurring adjacent to the normal parenchyma of the organs in the control and test animals. Probably, this may have occurred as a result of occult infection of the test colony with encephalitozoonosis. The lesions resulting from infiltrations were focal and isolated. Therefore, this allowed the evaluation of the effect of the test extracts on the normal cells in sections of the tissues that were not affected. Evidence of post-mortem changes was also observed in some organs that may have easily been confused with early stage of cell degeneration. These findings was collaborated by the fact that plasma enzymes was not elevated significantly in the test animals suggesting that the integrity of the organs was not adversely affected by a dose of $1000 \mathrm{mg} / \mathrm{kg}$ bw of $U$. diocia extracts (Figure 2).

\section{Qualitative and quantitative phytochemical and mineral screening}

Qualitative screening of aqueous extracts of $U$. dioica plants indicated the presence of phenols, alkaloids, flavonoids, saponins, tannins and phylobatannins. However, this was also established quantitatively except for phylobatannins. Cardiac glycosides were absent in the aqueous extracts of $U$. dioica (Table 10). In addition, the aqueous extracts of $U$. dioica contained $\mathrm{Cl}, \mathrm{K}, \mathrm{Ca}, \mathrm{Ti}, \mathrm{V}, \mathrm{Cr}, \mathrm{Mn}, \mathrm{Mg}, \mathrm{Fe}$, $\mathrm{Ni}, \mathrm{Cu}, \mathrm{Zn}, \mathrm{As}, \mathrm{Br}, \mathrm{Rb}$, and $\mathrm{Sr}$ at varying levels (Table 11).

\section{Discussion}

Alloxan acts as diabetogenic by the destruction of $\beta$-cells of the islets of langerhans and causes massive reduction in insulin release, thereby inducing hyperglycaemia [22]. Insulin deficiency leads to 
Citation: Mukundi MJ, Mwaniki NEN, Piero NM, Murugi NJ, Kelvin JK, et al. (2017) Potential Anti-diabetic Effects and Safety of Aqueous Extracts of Urtica dioica Collected from Narok County, Kenya. Pharm Anal Acta 8: 548. doi: 10.4172/2153-2435.1000548

\begin{tabular}{|c|c|c|c|c|c|c|c|}
\hline \multirow{2}{*}{ Treatment } & \multicolumn{7}{|c|}{ Glucose Levels at Varying Times (mmol/L) } \\
\hline & $\mathbf{O H}$ & $1 \mathrm{~h}$ & $2 \mathrm{~h}$ & $3 \mathrm{~h}$ & $4 \mathrm{~h}$ & $6 \mathrm{~h}$ & $24 \mathrm{~h}$ \\
\hline Control/Saline & $5.20 \pm 0.07$ & $5.20 \pm 0.07$ & $5.24 \pm 0.05$ & $5.18 \pm 0.08$ & $5.12 \pm 0.08$ & $5.08 \pm 0.08$ & $5.22 \pm 0.08$ \\
\hline Diabetic/Saline & $16.70 \pm 4.65$ & $18.54 \pm 4.50$ & $21.02 \pm 4.63$ & $22.68 \pm 4.36$ & $24.02 \pm 4.68$ & $25.60 \pm 3.73$ & $5.16 \pm 0.13$ \\
\hline Diabetic/Glen & $14.02 \pm 4.42$ & $11.00 \pm 4.39 a$ & $8.92 \pm 3.69 a$ & $7.08 \pm 2.07 a$ & $5.50 \pm 0.51 a$ & $5.08 \pm 0.21 a$ & $7.42 \pm 0.57 a$ \\
\hline $50 \mathrm{mg} / \mathrm{kg}$ bw & $12.38 \pm 2.20$ & $9.56 \pm 2.77 \mathrm{ac}$ & $6.02 \pm 1.38 \mathrm{ac}$ & $4.68 \pm 2.16 a$ & $4.26 \pm 2.00 a$ & $2.96 \pm 1.22 \mathrm{a}$ & $9.26 \pm 4.07 a$ \\
\hline $100 \mathrm{mg} / \mathrm{kg} \mathrm{bw}$ & $13.30 \pm 2.72$ & $9.32 \pm 3.20 \mathrm{ac}$ & $6.12 \pm 3.25 a c$ & $5.12 \pm 2.10 a$ & $4.40 \pm 1.46 a$ & $3.62 \pm 0.56 a$ & $8.16 \pm 4.55 a$ \\
\hline $200 \mathrm{mg} / \mathrm{kg} \mathrm{bw}$ & $12.36 \pm 0.52$ & $7.16 \pm 0.71 b c$ & $5.36 \pm 0.62 b c$ & $4.52 \pm 0.33 a$ & $4.38 \pm 0.38 a$ & $3.82 \pm 0.39 a$ & $8.08 \pm 1.70 a$ \\
\hline $300 \mathrm{mg} / \mathrm{kg} \mathrm{bw}$ & $14.20 \pm 2.61$ & $7.28 \pm 1.67 b c$ & $5.64 \pm 2.66 b c$ & $4.62 \pm 2.30 a$ & $3.78 \pm 1.55 a$ & $3.70 \pm 2.15 a$ & $7.06 \pm 2.14$ \\
\hline
\end{tabular}

Results are expressed as Means \pm SD for five animals per group. Values followed by the same superscript are not statistically different (P $\leq 0.05$; Analysed by ANOVA followed by Tukey's post hoc test)

Table 2: Effects of orally administered aqueous leaf extracts of Urtica dioica on blood glucose levels in alloxan induced diabetic mice.

\begin{tabular}{|c|c|c|c|c|c|c|}
\hline \multirow{2}{*}{ Treatment } & \multicolumn{5}{|c|}{ Weekly weight of mice (g) } & \multirow{2}{*}{$\begin{array}{c}\Delta \text { Weight/Week } \\
\text { (g/Week) }\end{array}$} \\
\hline & 0 & 1 & 2 & 3 & 4 & \\
\hline Control & $21.2 \pm 1.3$ & $23.0 \pm 1.1$ & $24.7 \pm 1.7$ & $26.2 \pm 1.8$ & $28.7 \pm 1.7$ & $1.89 \pm 0.39$ \\
\hline Urtica dioica & $22.0 \pm 2.1$ & $24.4 \pm 1.1$ & $26.0 \pm 1.0$ & $26.7 \pm 0.9$ & $27.2 \pm 0.8$ & $1.30 \pm 0.35^{*}$ \\
\hline
\end{tabular}

Results are expressed as Mean \pm SD for five animals per group. Means within respective columns followed by asterisk are significantly different from the control at $p<0.05$ by t-test; Key- $\Delta$-represents change in body weight

Table 3: Effects of orally administered aqueous plant extract of Urtica dioica on body weight of laboratory mice.

\begin{tabular}{|c|c|c|c|c|c|c|c|}
\hline \multirow{2}{*}{ Treatment } & \multicolumn{4}{|c|}{ Percent relative organ to body weight } \\
\cline { 2 - 7 } & Liver & Kidney & Heart & Lungs & Spleen & Testes & Brain \\
\hline Control & $5.82 \pm 1.17$ & $1.14 \pm 0.13$ & $0.40 \pm 0.03$ & $1.17 \pm 0.28$ & $0.87 \pm 0.29$ & $0.89 \pm 0.14$ \\
\hline Urtica dioica & $6.15 \pm 0.48$ & $1.30 \pm 0.10$ & $0.42 \pm 0.02$ & $1.04 \pm 0.15$ & $0.78 \pm 0.16$ & $0.58 \pm 0.06^{*}$ \\
\hline
\end{tabular}

Results are expressed as Mean \pm SD for five animals per group. Means within respective columns followed by asterisk are significantly different from the control at $p<0.05$ by t-test

Table 4: Effects of orally administered aqueous plant extract of Urtica dioica on relative organ weights of laboratory mice.

\begin{tabular}{|c|c|c|c|c|c|c|c|}
\hline \multirow{2}{*}{ Treatment } & \multicolumn{4}{|c|}{ Hematological parameters and indices } \\
\cline { 2 - 7 } & $\mathbf{R B C}(\times \mathbf{1 0} / \mathbf{\mu L})$ & $\mathbf{H b}(\mathbf{g} / \mathbf{d L})$ & $\mathbf{P C V}(\%)$ & $\mathbf{M C H}(\mathbf{p g})$ & $\mathbf{M C H C}(\mathbf{g} / \mathbf{d L})$ & $\mathbf{M C V}(\mathbf{f L})$ & $\mathbf{R D W}(\%)$ \\
\hline Control & $4.7 \pm 1.7$ & $7.2 \pm 2.7$ & $22.6 \pm 8.6$ & $15.1 \pm 0.9$ & $31.8 \pm 0.7$ & $47.5 \pm 3.0$ & $16.8 \pm 1.4$ \\
\hline Urtica dioica & $5.2 \pm 1.4$ & $7.5 \pm 1.9$ & $22.9 \pm 5.9$ & $14.5 \pm 0.3$ & $32.6 \pm 0.6$ & $44.3 \pm 1.2$ \\
\hline
\end{tabular}

Results are expressed as Mean \pm SD. Means within respective columns followed by asterisk are significantly different from the control at p<0.05 by T-test. RBC: Red Blood Cell Count; Hb: Hemoglobin; PCV: Packed Red Cell Volume; MCH: Mean Corpuscular Hemoglobin; MCHC: Mean Corpuscular Hemoglobin Concentration; MCV: Mean Corpuscular Volume; RDW: Red Cell Distribution Width

Table 5: Effects of orally administered aqueous plant extract of Urtica dioica on erythrocytes and related parameters in mice

\begin{tabular}{|c|c|c|c|c|c|c|c|c|c|}
\hline \multirow[b]{2}{*}{ Treatment } & \multicolumn{9}{|c|}{ Platelets, differential white blood cell count and other Hematological indices } \\
\hline & $\begin{array}{c}\text { WBC } \\
\left(\times 10^{3} / \mu \mathrm{L}\right)\end{array}$ & $\begin{array}{c}\text { LYM } \\
\left(\times 10^{3} / \mu \mathrm{L}\right)\end{array}$ & $\begin{array}{c}\text { MON } \\
\left(\times 10^{3} / \mu \mathrm{L}\right)\end{array}$ & $\begin{array}{c}\text { NEU } \\
\left(\times 10^{3} / \mu L\right)\end{array}$ & $\begin{array}{c}\text { EOS } \\
\left(\times 10^{3} / \mu L\right)\end{array}$ & $\begin{array}{c}\text { BAS } \\
\left(\times 10^{3} / \mu L\right)\end{array}$ & PLT $\left(\times 10^{3} / \mu L\right)$ & $\begin{array}{c}\text { MPV } \\
\text { (fL) }\end{array}$ & $\begin{array}{l}\text { PDW } \\
(\%)\end{array}$ \\
\hline Control & $11.4 \pm 4.7$ & $5.9 \pm 2.4$ & $0.9 \pm 0.4$ & $3.5 \pm 1.5$ & $1.1 \pm 0.4$ & $0.05 \pm 0.07$ & $191.2 \pm 60.7$ & $9.4 \pm 0.6$ & $15.5 \pm 0.2$ \\
\hline Urtica dioica & $12.9 \pm 2.1$ & $7.3 \pm 1.2$ & $0.9 \pm 0.1$ & $3.5 \pm 0.5$ & $1.1 \pm 0.2$ & $0.09 \pm 0.08$ & $271.2 \pm 66.2$ & $8.9 \pm 0.3$ & $15.4 \pm 0.1$ \\
\hline
\end{tabular}

Table 6: Effects of orally administered aqueous plant extract of Urtica dioica on platelets, differential white blood cell count and other related hematological indices in mice.

\begin{tabular}{|c|c|c|c|c|c|c|c|c|}
\hline \multirow[b]{2}{*}{ Treatment } & \multicolumn{8}{|c|}{ Enzyme activities } \\
\hline & $\begin{array}{l}\text { ALT } \\
\text { (U/L) }\end{array}$ & $\begin{array}{l}\text { AST } \\
\text { (U/L) }\end{array}$ & $\begin{array}{l}\text { ALP } \\
\text { (U/L) }\end{array}$ & GGT (U/L) & $\begin{array}{l}\text { LDH } \\
\text { (U/L) }\end{array}$ & $\begin{array}{c}\text { CK } \\
\text { (U/L) }\end{array}$ & $\begin{array}{c}\alpha-A M Y L \\
(U / L)\end{array}$ & AST/ALT \\
\hline Control & $46.8 \pm 13.2$ & $258.4 \pm 31.6$ & $10.4 \pm 4.4$ & $1.6 \pm 0.6$ & $1140.0 \pm 267.8$ & $9495.0 \pm 4783.5$ & $1292.8 \pm 274.7$ & $5.9 \pm 1.8$ \\
\hline Urtica dioica & $111.0 \pm 134.3$ & $365.6 \pm 293.9$ & $10.4 \pm 3.4$ & $2.4 \pm 1.5$ & $1473.0 \pm 250.9$ & $15283.0 \pm 7736.8$ & $23.0 \pm 163.6^{*}$ & $4.3 \pm 1.7$ \\
\hline
\end{tabular}

Results are expressed as Mean \pm SD. Means within respective columns followed by asterisk are significantly different from the control at $P<0.05$ by $T$-test. ALT: Alanine Transaminase; AST: Aspartate Transaminase; ALP: Alkaline Phosphatase; GGT: Y-glutamyltransferase; LDH: Lactate Dehydrogenase; CK: Creatine Kinase; a-AMYL: a-amylase; AST/ALT: The Ratio of the Activity of Aspartate Transaminase to Alanine Transaminase

Table 7: Effects of orally administered aqueous plant extract of Urtica dioica on enzyme markers of liver and kidney functions in mice.

\begin{tabular}{|c|c|c|c|}
\hline \multirow{2}{*}{ Treatment } & \multicolumn{3}{|c|}{ Analyte levels } \\
\cline { 2 - 4 } & CREAT $(\boldsymbol{\mu m o l} / \mathbf{L})$ & UREA (mmol/L) & BUN (mmol/L) \\
\hline Control & $13.8 \pm 3.8$ & $7.1 \pm 1.6$ & $3.3 \pm 0.8$ \\
\hline Urtica dioica & $19.2 \pm 4.8^{*}$ & $4.8 \pm 0.8$ & $62.8 \pm 26.0$ \\
\hline
\end{tabular}

Results are expressed as Mean \pm SD. Means within respective columns followed by asterisk are significantly different from the control at $\mathrm{P}<0.05$ by t-test. CREAT: Creatinine; UREA: Urea; BUN: Blood Urea Nitrogen; UA: Uric Acid

Table 8: Effects of orally administered aqueous plant extract of Urtica dioica on kidney functions in mice. 
Citation: Mukundi MJ, Mwaniki NEN, Piero NM, Murugi NJ, Kelvin JK, et al. (2017) Potential Anti-diabetic Effects and Safety of Aqueous Extracts of Urtica dioica Collected from Narok County, Kenya. Pharm Anal Acta 8: 548. doi: 10.4172/2153-2435.1000548

Page 5 of 8

\begin{tabular}{|c|c|c|c|c|c|c|c|c|}
\hline \multirow{2}{*}{ Treatment } & \multicolumn{8}{|c|}{ Lipid profiles and glucose levels } \\
\hline & T-BIL ( $\mu \mathrm{mol} / \mathrm{L})$ & D-BIL ( $\mu \mathrm{mol} / \mathrm{L})$ & I-BIL ( $\mu \mathrm{mol} / \mathrm{L})$ & TG (mmol/L) & $\mathrm{TC}(\mathrm{mmol} / \mathrm{L})$ & HDL-C (mmol/L) & LDL-C (mmol/L) & GLU (mmol/L) \\
\hline Control & $14.5 \pm 8.8$ & $7.2 \pm 4.0$ & $5.6 \pm 1.9$ & $1.35 \pm 0.77$ & $1.58 \pm 0.41$ & $0.70 \pm 0.32$ & $0.26 \pm 0.05$ & $5.0 \pm 1.0$ \\
\hline Urtica dioica & $16.6 \pm 4.7$ & $8.3 \pm 2.2$ & $8.3 \pm 2.7$ & $0.58 \pm 0.10$ & $1.06 \pm 0.21^{*}$ & $0.71 \pm 0.16$ & $0.08 \pm 0.04^{*}$ & $4.5 \pm 1.4$ \\
\hline
\end{tabular}

Results are expressed as Mean \pm SD. Means within respective columns followed by asterisk are significantly different from the control at P<0.05 by t-test. T-BIL: Total Bilirubin; D-BIL: Direct Bilirubin; I-BIL: Indirect Bilirubin; TG: Triacylglycerols; TC: Total Cholesterol; HDL-C: High Density Lipoprotein Cholesterol; LDL-C: Low Density Lipoprotein Cholesterol; GLU: Glucose

Table 9: Effects of orally administered aqueous plant extracts on lipid profiles and glucose levels in mice.

\begin{tabular}{|c|c|c|c|c|c|}
\hline Phytochemicals & Phenols $\mathbf{( m g / g )}$ & $\begin{array}{c}\text { Alkaloids } \\
\mathbf{( g / 1 0 0 g})\end{array}$ & Flavonoids (mg/g) & Saponins (g/100g) & Tannins (mg/g) \\
\hline \multirow{2}{*}{ Urtica dioica } & ++ & ++ & ++ & ++ \\
\hline & 2.11 & 0.08 & 1.01 & 4.85 & ++ \\
\hline
\end{tabular}

Table 10: Phytochemical composition of the aqueous extract of Urtica dioica leaves extract.

\begin{tabular}{|c|c|c|}
\hline Mineral & Urtica dioica & RDA ( $\mu \mathrm{g} /$ day) \\
\hline \multirow{2}{*}{$\mathrm{Cl}$} & $1030 \pm 27$ & \multirow{2}{*}{ - } \\
\hline & 25.75 & \\
\hline \multirow{2}{*}{$\mathrm{K}$} & $34691 \pm 479$ & \multirow{2}{*}{$2.0 \times 10^{6}$} \\
\hline & 867.28 & \\
\hline \multirow{2}{*}{$\mathrm{Ca}$} & $36788 \pm 295$ & \multirow{2}{*}{$1.0 \times 10^{3}$} \\
\hline & 919.70 & \\
\hline \multirow{2}{*}{$\mathrm{Ti}$} & $9.10 \pm 0.62$ & \multirow{2}{*}{0.015} \\
\hline & 0.2275 & \\
\hline \multirow{2}{*}{$\mathrm{V}^{*}$} & 0 & \multirow{2}{*}{0.064} \\
\hline & 0 & \\
\hline \multirow{2}{*}{$\mathrm{Cr}^{*}$} & 0 & \multirow{2}{*}{0.01} \\
\hline & 0 & \\
\hline \multirow{2}{*}{$\mathrm{Mn}$} & $58.00 \pm 1.30$ & \multirow{2}{*}{$2.3 \times 10^{3}$} \\
\hline & 1.5 & \\
\hline \multirow{2}{*}{$\mathrm{Mg}^{*}$} & 156.5 & \multirow{2}{*}{150} \\
\hline & 3.9125 & \\
\hline \multirow{2}{*}{$\mathrm{Fe}$} & $246 \pm 27$ & \multirow{2}{*}{$8.0 \times 10^{3}$} \\
\hline & 6.15 & \\
\hline \multirow[t]{2}{*}{$\mathrm{Ni}$} & $2.27 \pm 0.81$ & \multirow{2}{*}{ - } \\
\hline & 0.05675 & \\
\hline \multirow{2}{*}{$\mathrm{Cu}$} & $6.27 \pm 0.64$ & \multirow{2}{*}{0.32} \\
\hline & 0.15675 & \\
\hline \multirow{2}{*}{$\mathrm{Zn}$} & $37.10 \pm 0.80$ & \multirow{2}{*}{$1.1 \times 10^{4}$} \\
\hline & 0.9275 & \\
\hline \multirow{2}{*}{ As } & $1.10 \pm 0.28$ & \multirow{2}{*}{-} \\
\hline & 0.0275 & \\
\hline \multirow{2}{*}{$\mathrm{Br}$} & $26.10 \pm 0.90$ & \multirow{2}{*}{0.08} \\
\hline & 0.6525 & \\
\hline \multirow{2}{*}{$\mathrm{Rb}$} & $18.30 \pm 1.30$ & 0.005 \\
\hline & 0.4575 & 0.005 \\
\hline & $263 \pm 11$ & \\
\hline Sr & 6.575 & - \\
\hline & 0 & \\
\hline $\mathrm{Hg}$ & 0 & - \\
\hline & $1.33 \pm 0.45$ & \\
\hline PD & 0.03325 & - \\
\hline
\end{tabular}

Values of trace elements with a star as a superscript were determined using the AAS. The figures on the upper side show concentration of minerals contained in the lyophilized extracts in $\mathrm{mg} / \mathrm{g}$. Figures on the lower side show the daily amount of the mineral that was injected in the animals in mg/g

Table 11: Mineral levels $(\mu \mathrm{g} / \mathrm{g}$ ) and their quantity in $25 \mathrm{mg}$ aqueous plant extract of Urtica dioica administered to each mouse per day ( $\mu \mathrm{g} / \mathrm{day}$ ).

various metabolic alterations in the animals viz increased blood glucose, increased cholesterol, increased levels of alkaline phosphate and transaminases $[23,24]$. The results of the present study showed that oral administration of the lyophilised aqueous extracts of Urtica dioica at various doses decreased significantly plasma glucose levels over a period of $0-6 \mathrm{~h}$ in alloxan induced diabetic mice. In another study involving extracts of Tribulus terrestris it was found that it significantly decreased blood glucose level in normal and alloxan-induced diabetic mice, mainly due to the increased serum insulin level [25]. 
Citation: Mukundi MJ, Mwaniki NEN, Piero NM, Murugi NJ, Kelvin JK, et al. (2017) Potential Anti-diabetic Effects and Safety of Aqueous Extracts of Urtica dioica Collected from Narok County, Kenya. Pharm Anal Acta 8: 548. doi: 10.4172/2153-2435.1000548

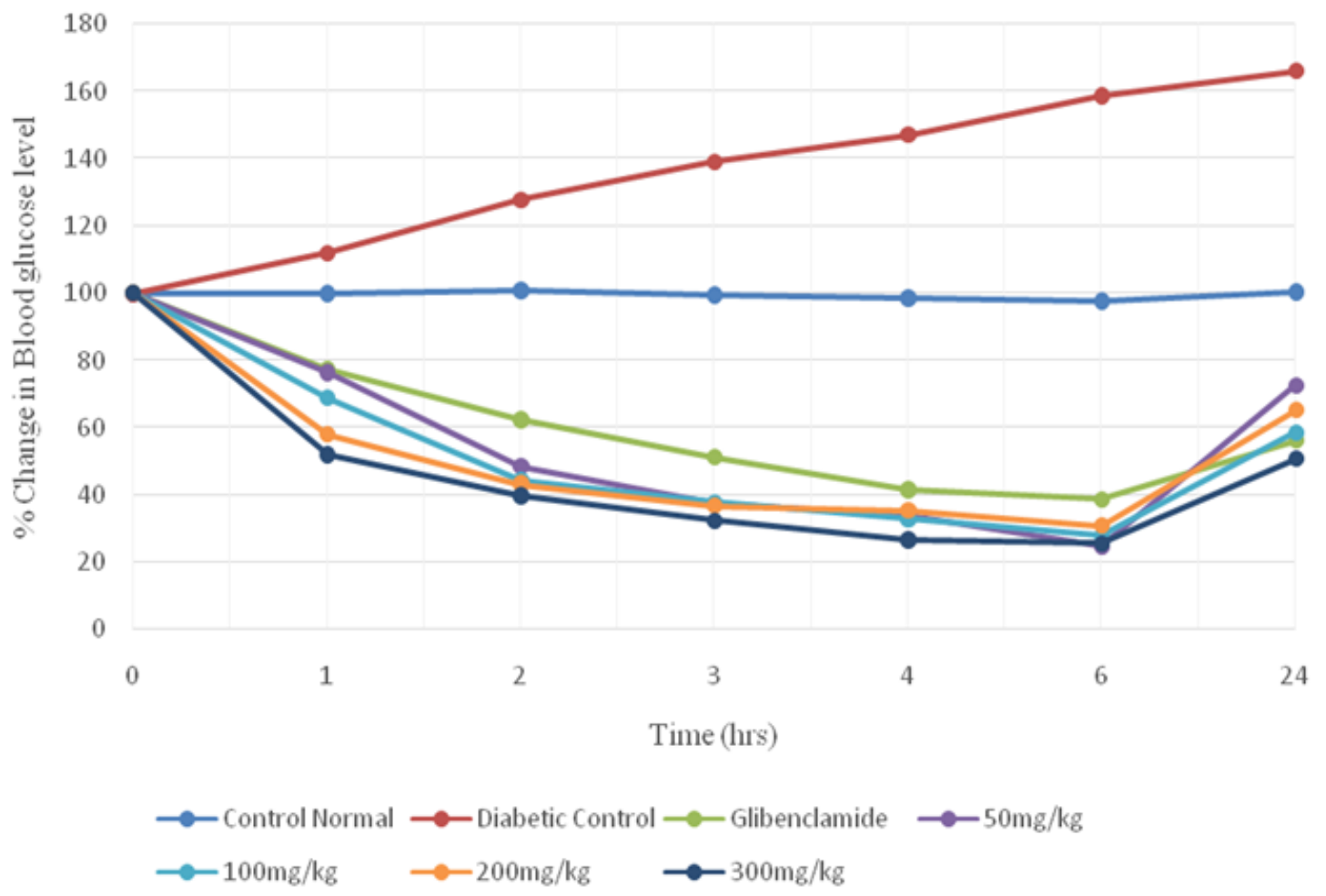

Figure 1: Mean percentage change in blood glucose levels of aqueous leaf extracts of Urtica dioica administered orally in alloxan induced diabetic mice.


Figure 2: Histological plates of body organs following oral administration of Urtica dioica at $1000 \mathrm{mg} / \mathrm{kg}$ body weight (Magnification: X100): Kidney $(A)$, Liver (B), Brain (C), Heart (D), Lungs (E), Testis (F), Spleen (G) and Intestines $(H)$. Sections with focal mononuclear cell infiltration are marked with $(\mathrm{x})$.
Theoretically, hypoglycemic plants act through a variety of mechanisms. Some studies report the association of the effects of the plant extracts on the activity of pancreatic $\beta$-cells, increase in the inhibitory effect against insulin enzyme, increase in the sensitivity of insulin or the insulin-like activity of the plant extracts. Other mechanisms may also be involved; such as increase of peripheral utilization of glucose, increase of synthesis of hepatic glycogen or decrease of glycogenolysis, inhibition of intestinal glucose absorption, reduction of glycaemic index of carbohydrates and reduction of the effect of glutathione [26].

The phytochemical studies of $U$. dioica extract revealed the presence of tannins, saponins, flavonoids, alkaloids and phenols. Flavonoid and terpenes isolated from other anti-diabetic medicinal plants have been found to stimulate secretion or possess an insulin like-effect [27]. Flavonoids quercetin and ferulic acid have an effect on pancreatic $\beta$-cells, they promote $\beta$-cells proliferation leading to the secretion of more insulin in streptozocin induced diabetic rats [28,29]. Probably, this is the mechanism by which hyperglycaemia was lowered in the alloxan induced diabetes in this study on mice.

Medicinal herbs used in indigenous medicines for the management of diabetes mellitus contain both organic and inorganic constituents. Some of these inorganic trace elements possess anti-diabetic properties, which could account for the activity of medicinal herbs [30]. Trace elemental analysis of $U$. dioica compares with those established in other studies using different types of plants; Tinospora cordifolia, Withania somnifera, Eugenia jambolana, Cassia auriculata, Gymnema sylvestris, Adhathoda vasica, Ocimum sanctum, and Azadirachta indica are using PIXE technique. All this plants are proven to possess anti-diabetic activity. Moreover, they have common mineral elements identified in 
Citation: Mukundi MJ, Mwaniki NEN, Piero NM, Murugi NJ, Kelvin JK, et al. (2017) Potential Anti-diabetic Effects and Safety of Aqueous Extracts of Urtica dioica Collected from Narok County, Kenya. Pharm Anal Acta 8: 548. doi: 10.4172/2153-2435.1000548

each of the plants, such as $\mathrm{Cl}, \mathrm{K}, \mathrm{Ca}, \mathrm{Ti}, \mathrm{Cr}, \mathrm{Mn}, \mathrm{Fe}, \mathrm{Ni}, \mathrm{Cu}, \mathrm{Zn}, \mathrm{Br}, \mathrm{Rb}$ and $\mathrm{Sr}$ [31]. This study also indicated the presence of these minerals in $U$. dioica. The blood glucose lowering effect by the aqueous extracts of $U$. dioica used in this study could also have been caused by trace elements that were revealed to be present in it.

The results from this study revealed that the plant extracts of $U$. dioica did not significantly alter the liver, kidney and lipid biomarkers for organ damage in this study. In other findings, a lower dose of 450 $\mathrm{mg} / \mathrm{kg}$ body of aqueous extracts of $U$. dioica showed protection against induced liver damage suggesting it was not toxic. Similarly, there were no significant changes in the red blood cells and haemoglobin and their related indices at a dose of $1000 \mathrm{mg} / \mathrm{kg}$ bw. These was also maintained at lower doses of $450 \mathrm{mg} / \mathrm{kg}$ bw [32]. This is an indication that the extract has no stimulatory effect on the humoral regulator of RBC production and on erythropoietin $[33,34]$. There was no significant damage caused on the body organs in this study. This was supported by the nonsignificant change in body organs weight

\section{Conclusion}

For a long time, the hypoglycemic effects of Urtica dioica have been purely speculative. Experimental evidence obtained from this study indicated that $U$. dioica possess anti-diabetic property. All the four doses at $50 \mathrm{mg} / \mathrm{kg} \mathrm{bw}, 100 \mathrm{mg} / \mathrm{kg}$ bw, $200 \mathrm{mg} / \mathrm{kg}$ bw and $300 \mathrm{mg} / \mathrm{kg}$ bw produced an effect comparable to that of glibenclamide. Thus it could serve as good adjuvant to other oral hypoglycemic agents and seems to be promising for the development of phytomedicines for mannagement of Diabetes mellitus. Safety of the plant extract was also confirmed by results obtained from biochemical, hematological, organ weights and histopathological examination of tissues from different organs.

\section{Acknowledgement}

We specially recognize the technical contributions of Mr. James Adino, Wycliff Wenwa, Mr. Patrick Muiruri and Josephine Wokabi from the department of Biochemistry and Biotechnology, Kenyatta University for their technical assistance at the Animal House. Mr. Simon Bartilol, Department of Nuclear science, University of Nairobi for assistance on Mineral analysis. Mr. Jackson Gachoka, David Muriithi, Dr. Dhaval Shah, John Mukiri, Ezekiel Weda and Mary Muthoni; Department of Veterinary Pathology and Microbiology, University of Nairobi (U.O.N) for helping in the preparation of histological slides. Mr. Mathias M. Mbale of Kenya National Museum for assisting in identification and verification of plant specimens and finally Mr. Dismus Luchiti of Technical University of Kenya (TUK) for his contribution in generating the geographical coordinates.

\section{References}

1. Wild S, Rolglic G, Green A, Sicress R, King H (2004) Global prevalence of diabetes. Diabetes Care 27: 1047-1053.

2. Patel DK, Kumar D, Loo SH (2012) Diabetes mellitus: An overview on its pharmacological aspects and reported medicinal plants having anti-diabetic activity. Asian Pac J Trop Biomed 2: 411-420.

3. Wadkar AK, Magdum CS, Patil SS, Naikwade SN (2008) Anti-diabetic potential and Indian medicinal plants. J Herb Med Toxicol 2: 45-50.

4. Joseph B, Jini D (2013) Anti-diabetic effects of Momordica charantia (bitter melon) and its medicinal potency. Asian Pac J Trop Dis 32: 93-102.

5. Zhou T, Luo D, Li X, Luo Y (2009) Hypoglycemic and hypolipidemic effects of flavonoids from lotus (Nelumbo nuficera Gaertn) leaf in diabetic mice. J Med Plant Res 3: 290-293.

6. The World Health Organization (WHO) (2002) WHO launches the first global strategy on traditional medicine: Press release WHO/38.

7. Nagarajan S, Jain HC, Aulakh GS (1987) Indigenous plants used in the contro of diabetes. Publication and Information Directorate, C.S.I.R., New Delhi, India p: 588

8. Grover JK, Vats V, Rathi SS (2000) Antihyperglycemic effect of Eugenia jambolana and Tinospora cordifolia in experimental diabetes and their effects on key metabolic enzymes involved in carbohydrate metabolism. $J$ Ethnopharmacol 73: 461-470.

9. Mikaeili A, Karim I, Modares M, Bagherinasab Z (2013) Assessment of Antidermatophytic Activities of Urtica dioica L. against Microsporum canis in a Guinea Pig model. Trop J Pharm Res 12: 997-1002.

10. Rashidi AA, Mirhashemi MS, Taghizade M, Sarkhail P (2013) Iranian medicinal plants for Diabetes mellitus. A systematic review. Pak J Biol Sci 16: 401-411.

11. Phs PH (1986) Public health service policy on humanne care and use of laboratory animals. Washington DC: Department of Health and Human Services.

12. Karau GM (2013) Biosprospecting of anti-diabetic compounds from selected medicinal plants for the management of Diabetes Mellitus in Mbeere and Meru, Kenya, PhD Thesis.

13. Henry RJ, China N, Golubo J, Berkman S (1960) Serum transaminase in live disease. J Am Med Assoc 163: 1461-1465.

14. Jain NC (1986) Schalm's veterinary haematolgy (4 $4^{\text {th }}$ edn.). Philadelphia: Lea and Febiger.

15. Abdirahman YA, Juma KK, Makori WA, Agyirifo DS, Ngugi MP, et al. (2015) Blood glucose lowering effect and safety of the aqueous leaf extracts of Zanha Africana. Pharm Anal Act 6: 1-9.

16. Baker FJ, Silverton RE, Luckcock ED (1989) An introduction to medical laboratory technology ( $4^{\text {th }}$ edn.). London, UK.

17. Rasool R, Ganai BA, Akbar S, Kamili N, Masood A (2010) Phytochemical screening of Prunella vulgaris L. An important medicinal plant of Kashmir. Pak J Pharmaceut Sci 23: 399-402.

18. Rasool R, Ahmad BG, Akba S, Nahaid AK, Younusm MD et al. (2013) Variation in bioactive principles of Artemisia amygdalina Decne in wild and tissue culture regenerants. Pak J Pharm Sci 26: 623-628.

19. Mir AM, Sawhney SS, Jassal SMM (2013) Quantitative and qualitative analysis of phytochemicals of Taraxacum officinale (Wudpecker). J Pharm Pharmacol 2: 001-005.

20. Hagen S (2007) S2 PICOFOX; Total Reflection x-ray fluorescence spectroscopy-working principles.

21. Piero NM, Njagi MJ, Kibiti MC, Maina D, Ngeranwa JJ, et al. (2015) Trace elements content of selected Kenyan anti-diabetic medicinal plants. Int $\mathrm{J}$ Cur Pharm Res 4: 39-42.

22. Grover JK, Yadav S, Vats V (2002) Medicinal plants of India with anti-diabetic potential. J Ethnopharmacol 81: 81-100.

23. Shanmugasundaram KR, Panneerselvam SP, Shanmugasundaram ERB (1983) Enzyme changes and glucose utilization in diabetic rabbit: the effect of Gymnema sylvestrae, R. Brit J Ethnopharm 7: 205-216

24. Begum N, Shanmugasudnaram KR (1978) Tissue phosphates in experimental diabetes. Aro J Health Sci 4: 129-139.

25. Chauhan A, Sharma PK, Srivastava P, Kumar N, Duehe R (2010) Plants having potential anti-diabetic activity: A review. Der Pharm Let J 2: 369-387.

26. Bnouham M, Ziyyat A, Mekhfi $H$, Tahri A, Legssyer A (2006) Medicinal plant with potential anti-diabetic activity-a review of ten years of herbal medicine research (1990-2000). Int J Diabetes Metabol 14: 1-25.

27. Marles JR, Farnsworth NR (1995) Anti-diabetic plants and their active constituents. Phytomedicine 2: 123-189.

28. Mahesh T, Menon PV (2004) Quercetin alleviates oxidative stress in streptozotocin induced diabetic rats. Phytother Res 18: 123-127.

29. Sri Balasubashini M, Rukkumani R, Viswanathan P, Menon PV (2004) Ferulic acid alleviates lipid peroxidation in diabetic rats. Phytother Res 18: 310-314.

30. Njagi JM, Ngugi MP, Kibiti CM, Ngeranwa NJ, Njagi J (2012) Hypoglycemic effects of Caesalpina volkensii on alloxan induced Diabetic Mice. Asian J Pharm Clin Res 5: 74-76.

31. Raju GN, Sarita P, Murty GR, Kumar MR, Reddy BS, et al. (2006) Estimation of trace elements in some anti-diabetic medicinal plants using PIXE technique. Appl Radiat Isotopes 64: 893-900.

32. Juma KK, Maina SG, Muriithi JN, Mwangi BM, Mworia KJ, et al. (2015) 
Citation: Mukundi MJ, Mwaniki NEN, Piero NM, Murugi NJ, Kelvin JK, et al. (2017) Potential Anti-diabetic Effects and Safety of Aqueous Extracts of Urtica dioica Collected from Narok County, Kenya. Pharm Anal Acta 8: 548. doi: 10.4172/2153-2435.1000548

Page 8 of 8

Protective effects of Urtica dioica and Cimetidine ${ }^{\circledR}$ on Liver function following acetaminophen Induced hepatotoxicity in Mice. J Dev Drug 4: 130

33. Sanchez-Elsner T, Ramirez JR, RodriguezSanz F, Varela E, Bernabew, et al (2004) Cross talk between hypoxia and TGF-beta orchestrates erythropoietin gene regulation through SPI and smads. J Mol Biol 336: 9-24.
34. Yakubu MT, Afolayan AJ (2009) Effect of aqueous extract of Bulbine natalensis baker stem on haematological and serum lipid profile of male Wistar rats. Ind J Exp Biol 47: 283-288. 